\title{
Renal thrombotic microangiopathy in patients with cblC defect: review of an under-recognized entity
}

\author{
Bodo B. Beck ${ }^{1}$ - FrancJan van Spronsen ${ }^{2}$ - Arjan Diepstra ${ }^{3}$ • Rolf M. F. Berger ${ }^{4}$. \\ Martin Kömhoff ${ }^{5,6}$
}

Received: 16 September 2015 / Revised: 10 April 2016/Accepted: 11 April 2016/Published online: 11 June 2016

(C) The Author(s) 2016. This article is published with open access at Springerlink.com

\begin{abstract}
Methylmalonic aciduria and homocystinuria, cobalamin $\mathrm{C}$ (cblC) type, is the most common genetic type of functional cobalamin (vitamin $\mathrm{B}_{12}$ ) deficiency. This metabolic disease is characterized by marked heterogeneity of neurocognitive disease (microcephaly, seizures, developmental delay, ataxia, hypotonia) and variable extracentral nervous system involvement (failure to thrive, cardiovascular, renal, ocular) manifesting predominantly early in life, sometimes during gestation. To enhance awareness and understanding of renal disease associated with cblC defect, we studied biochemical, genetic, clinical, and histopathological data from 36 patients. Consistent clinical chemistry features of renal disease
\end{abstract}

Electronic supplementary material The online version of this article (doi:10.1007/s00467-016-3399-0) contains supplementary material, which is available to authorized users.

Martin Kömhoff

martin.komhoff@yahoo.com

1 Institute of Human Genetics, University of Cologne, Cologne, Germany

2 Division of Metabolic Diseases, Beatrix Children's Hospital, University Medical Centre Groningen, University of Groningen, Groningen, The Netherlands

3 Department of Pathology and Medical Biology, University Medical Centre Groningen, University of Groningen,

Groningen, The Netherlands

4 Centre for Congenital Heart Diseases-Paediatric Cardiology, University Medical Centre Groningen, University of Groningen, Groningen, The Netherlands

5 Division of Paediatric Nephrology, Beatrix Children's Hospital, University Medical Centre Groningen, University of Groningen, Groningen, The Netherlands

6 University Children's Hospital, Philipps University Marburg, Baldinger Str., 35043 Marburg, Germany were intravascular hemolysis, hematuria, and proteinuria in all patients, with nephrotic-range proteinuria observed in three. Renal function ranged from normal to renal failure, with eight patients requiring (intermittent) dialysis. Two thirds were diagnosed with atypical (diarrhea-negative) hemolytic uremic syndrome (HUS). Renal histopathology analyses of biopsy samples from 16 patients revealed glomerular lesions typical of thrombotic microangiopathy (TMA). Treatment with hydroxycobalamin improved renal function in the majority, including three in whom dialysis could be withdrawn. Neurological sequelae were observed in $44 \%$ and cardiopulmonary involvement in $39 \%$ of patients, with half of the latter group demonstrating pulmonary hypertension. Mortality reached $100 \%$ in untreated patients and 79 and $56 \%$ in those with cardiopulmonary or neurological involvement, respectively. In all patients presenting with unclear intravascular hemolysis, hematuria, and proteinuria, cblC defect should be ruled out by determination of blood/plasma homocysteine levels and/or genetic testing, irrespective of actual renal function and neurological status, to ensure timely diagnosis and treatment.

Keywords Atypical hemolytic uremic syndrome $\cdot$ Cobalamin $\mathrm{C}$ defect $\cdot$ Pulmonary arterial hypertension $\cdot$ Children

\section{Introduction}

Vitamin $\mathrm{B}_{12}$, also known as cobalamin $(\mathrm{Cbl})$, is a complex water-soluble organic compound that is essential to all animals and numerous microorganisms. From an evolutionary perspective, vitamin $B_{12}$ is an extremely old molecule, which has even been suggested to be synthesized prebiotically [1]. Synthesis is limited to several archaea and eubacteria and requires more than 25 steps [2]. The standard Western diet contains 5-7 $\mu \mathrm{g}$ 
of $\mathrm{Cbl}$ per day, which comes exclusively from dairy products and meat. The liver stores sufficient $\mathrm{Cbl}$ for several years, even after intake has completely ceased. The absorption, transport, storage, and intracellular processing of $\mathrm{Cbl}$ is complex, as is reflected by the high number of at least 21 genes that are known to affect $\mathrm{Cbl}$ absorption, storage, and metabolism in humans [3]. Vitamin $\mathrm{B}_{12}$ deficiency can thus result from numerous primary (genetic) and secondary conditions.

The most common disorder of intracellular vitamin $\mathrm{B}_{12}$ metabolism is methylmalonic aciduria and homocystinuria, cblC complementation type (MMACHC; phenotype MIM\# 277400 ), which accounts for $\sim 80 \%$ of all cases. MMACHC has also been designated as cblC defect, cobalamin deficiency, $\mathrm{C}$ type, or cobalamin $\mathrm{C}$ deficiency. The last two terms could be confused with mere $\mathrm{Cbl}$ deficiency/absence (i.e., nutritional $\mathrm{Cbl} / \mathrm{B}_{12}$ deficiency). To avoid erroneous exclusion of MMACHC based on the observation of normal or even elevated plasma $B_{12}$ levels typically seen in affected individuals, the designations MMACHC or cblC defect is used throughout this review for the autosomal recessive metabolic disorder [4]. MMACHC was first described clinically in 1969 in a child with severe neurological compromise, hyperhomocysteinemia (-uria) with low methionine concentrations, and methylmalonic acidemia/aciduria, who died at 8 weeks of age [5]. Patients with MMACHC show downstream cytoplasmic blocking of $\mathrm{Cbl}$ conversion, resulting in combined deficiency of two important cofactors: adenosylcobalamin (AdoCbl) and methylcobalamin (MeCbl) [6]. $\mathrm{MeCbl}$ is the coenzyme for methionine synthase (MTR; defective in autosomal recessive cblG complementation type) required for the conversion of homocysteine to methionine in the cytoplasm. When this reaction is impaired, deranged folate metabolism causes - via defective DNA synthesis- the megaloblastic maturation pattern observed in these patients. AdoCbl is the cofactor of the mitochondrial enzyme methylmalonyl coenzyme A $(\mathrm{CoA})$ mutase (itself defective in autosomal recessive methylmalonic acidemia, cblA, or cblB complementation type caused by mutations in either the MMAA or $M M A B$ gene), which converts L-methylmalonyl-CoA to succinyl-CoA. In the absence of AdoCbl, methylmalonic acid is generated from excess of L-methylmalonyl-CoA (Fig. 1).

This explains the biochemical hallmarks of MMACHC (Table 1): hyperhomocysteinemia/hyperhomocystinuria with low methioninemia, and methylmalonic acidemia/aciduria (which is also the biochemical phenotype seen in the rarer complementation types cblD, cblF, cblJ, and cblX variants [3]).

The clinical findings are summarized in Table 2 and are described in detail in a recent review [4].

The gene MMACHC (MIM\# 609831) was identified in 2006 [9] and is located on chromosome 1p34 and contains only four coding exons. The complementary DNA (cDNA) has an 846-bp open reading frame encoding a protein of 282 amino acids with a predicted molecular weight of $31.7 \mathrm{kD}$.

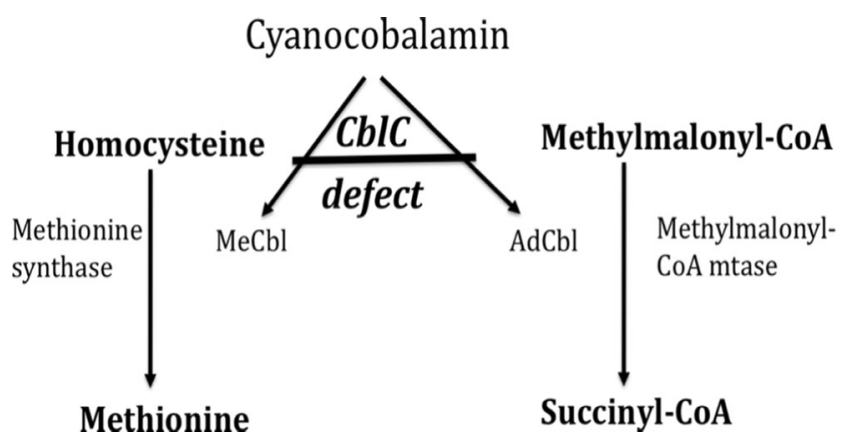

Fig. 1 Methylmalonic aciduria and homocystinuria, cobalamin C (cblC) complementation type (MMACHC) is required for decyanation of cyanocobalamin, a precursor for subsequent conversion into the essential cofactors methylcobalamin ( $\mathrm{MeCbl})$ and adenosylcobalamin (AdoCbl). MeCbl is required to metabolize homocysteine to methionine, and AdoCbl is needed for the breakdown of methylmalonic acid. This scheme illustrates why cyanocobalamin is largely ineffective to treat cblC defect and why blood levels of both homocysteine and methylmalonic acid are increased while methionine concentrations are reduced (modified from [7], used with permission)

Contrary to the $\mathrm{N}$-terminal domain of the protein (MMACHC), which lacks homology to any known protein, homology exists between the $\mathrm{C}$-terminal domain and the bacterial protein TonB [9], a Cbl-binding protein [10].

The MMACHC protein (Uniprot KB entry Q9Y4U1) possesses decyanase, dealkylase, and flavin reductase activities. Decyanation of cyanocobalamin is essential for its subsequent conversion into the active cofactors adenosylcobalamin and methylcobalamin (Fig. 1) [11]. This explains why MMACHC patients do not respond to therapy with orally administered cyanocobalamin and should be treated with hydroxycobalamin i.m., which can be metabolized into adenosylcobalamin and methylcobalamin. MMACHC knockout mice die from preimplantation defect [12]. During midgestation in murine development, MMACHC is expressed in many tissues, including the mesonephric mesenchyme of the kidney and the endothelium of blood vessels and heart [13, 14]. MMACHC represents the prototypic and most common disorder of intracellular $\mathrm{Cbl} \mathrm{me-}$ tabolism; currently, 81 different mutations [Human Gene Mutation Database (HGMD) professional 2015.4), and well over 500 patients have been reported worldwide [9, 15-17]. The frameshift mutation c.271dupA (p.R91KfsX14) accounts for about $40 \%$ of disease-causing alleles in the Caucasian population [15], while c.609G $>$ A (p.R161X) has been

Table 1 Key laboratory parameters in cobalamin C (cblC) defect

\begin{tabular}{lll}
\hline Test & Normal range & Patients \\
\hline Plasma tHCY $(\mu \mathrm{m})$ & $5-15$ & $23-186$ \\
Plasma MMA $(\mu \mathrm{m})$ & $<0.27$ & $1.6-14.5$ \\
Plasma $B_{12}$ levels $(\mathrm{pg} / \mathrm{ml})$ & $170-800$ & $611-932$ \\
\hline
\end{tabular}

tHCY total homocysteine, MMA methylmalonic acid 
Table 2 Clinical synopsis of myriad methylmalonic aciduria and homocystinuria, cobalamin C (cblC) complementation type (MMACHC) manifestations (modified from [8], used with permission)

\begin{tabular}{|c|c|}
\hline System & Clinical manifestations \\
\hline Growth and habitus & $\begin{array}{l}\text { Prenatal growth retardation } \\
\text { Postnatal failure to thrive } \\
\text { Microcephaly } \\
\text { Hydrops fetalis } \\
\text { Hydrocephalus } \\
\text { Marfanoid habitus } \\
\text { Dysmorphic facial features }\end{array}$ \\
\hline Central nervous system & $\begin{array}{l}\text { Developmental delay } \\
\text { Seizures } \\
\text { Ataxia } \\
\text { Hypotonia } \\
\text { Lethargy, progressive encephalopathy } \\
\text { Regression, dementia } \\
\text { Cognitive impairment ranging from executive } \\
\text { dysfunction to severe mental retardation } \\
\text { Neuropsychiatric disturbances } \\
\text { Subdural hematoma } \\
\text { Demyelinating neuropathy } \\
\text { Leukoencephalopathy } \\
\text { Basal ganglia lesions (less frequent) }\end{array}$ \\
\hline Eye & $\begin{array}{l}\text { Maculopathy } \\
\text { Retinal degeneration } \\
\text { Optic atrophy } \\
\text { Nystagmus }\end{array}$ \\
\hline Blood & Anemia, thrombocytopenia and/or neutropenia, megaloblastosis \\
\hline Vascular & $\begin{array}{l}\text { Recurrent venous thrombosis } \\
\text { Cor pulmonale or subclinical pulmonary thrombosis } \\
\text { Cerebrovascular complications, stroke }\end{array}$ \\
\hline Renal & $\begin{array}{l}\text { Hemolytic-uremic syndrome } \\
\text { Chronic thrombotic microangiopathy } \\
\text { Nephrotic syndrome } \\
\text { Renal failure }\end{array}$ \\
\hline Heart & $\begin{array}{l}\text { Fetal dilated cardiomyopathy } \\
\text { Congenital heart defects } \\
\text { Pulmonary arterial hypertension } \\
\text { Left ventricular noncompaction }\end{array}$ \\
\hline
\end{tabular}

identified as the most frequent mutation in a study from China [16]. Early-onset disease, defined as manifestation within the first year of life, has been associated with the truncating alleles c.271dupA or c.331C>T (p.R111X) [15]. Two recent studies found incidence rates ranging from 1:100,000 births in the New York, USA, region [13] to 1: 60,000 in California, USA and up to $1: 37,000$ in the Hispanic population. French Canadian, Cajun, Indian, Chinese, Middle Eastern, and European populations are believed to be at an increased risk for cblC type [8].

Although MMACHC constitutes a multisystemic disease that can affect almost any organ system, including the kidney (see overview in Table 2), cblC defect is largely regarded as a disease affecting central nervous system (CNS) development and neurocognition [18]. In 1979, Baumgartner and her colleagues described the first patient with renal disease and MMACHC defect [19]. The boy from unrelated Italian parents presented in the neonatal phase with failure to thrive and anemia. At 3 months of age, he was diagnosed with elevated methylmalonic acid and homocysteine concentrations in blood and urine. Treatment with cyanocobalamin was unsuccessful. Severe metabolic acidosis and uremia were noted. He developed progressive arterial hypertension, hepatomegaly, and 
tachypnea. On chest X-ray, cardiomegaly and pulmonary edema were noted. Digoxin and furosemide led to some improvement, but at the age of 4 months, he had a second episode of heart failure and died a few hours later from intractable pulmonary edema. From the first report until to date, at least 36 patients with cblC defect and thrombotic microangiopathy (TMA) have been identified worldwide. The purpose of this review is to increase awareness of the renal manifestation and outcome in MMACHC.

MMACHC as a treatable form of TMA has received comparatively little attention in the field, as is reflected by its omission in several reviews on TMAs. This is very unfortunate, as the mortality rate of patients with MMACHC is high, while initial screening for elevated homocysteine plasma/ blood levels is widely available, fast, and inexpensive ( US \$30). Unlike in other rare kidney diseases, a causal therapeutic option, hydroxycobalamin, is readily available. Treatment with hydroxycobalamin is effective in many patients when started early, it has minimal side effects, and it is available at negligible costs (US \$1/day).

\section{Methods}

We reviewed clinical data from patients referred to our institutions as well as from published case reports and case series of renal disease in patients with MMACHC. The supplemental table lists biochemical data and provides clinical information of patients with MMACHC for whom individual clinical details of renal disease were available. PubMed search terms included cblC, cobalamin, MMACHC, renal, and kidney.

\section{Results}

We identified 36 patients $([14,21-38]$, including one unpublished patient) with established cblC defect and renal involvement. Diagnosis of MMACHC was confirmed biochemically in 34 patients and genetically in 18 (Table 3; for individual data, see Table S1). The most frequent MMACHC mutations in our cohort were c.271dupA (36\% allelic frequency), c.276G $>\mathrm{T}$ (17\% allelic frequency), and c.565C >A ( $11 \%$ allelic frequency, Fig. 2). Most MMACHC cases were sporadic, while familial disease was noted in three sets of siblings (patient numbers 18 and, 24, 26 and 30, 27 and 28 in Table S1). Infantile onset ( $<12$ months of age) was observed in 16 patients, and 20 patients presented with TMA beyond infancy (Table 4).

All patients were clinically diagnosed with TMA characterized by (microvascular thrombosis with) thrombocytopenia, hemolytic anemia, and red blood cell fragmentation [39]. Twenty-four of the 36 patients met (diarrhea-negative) hemolytic uremic syndrome (HUS) criteria defined by the
Table 3 Disease onset and diagnosis of cobalamin C (cblC) and complement data: findings in 36 patients with cblC defect and thrombotic microangiopathy

\begin{tabular}{ll}
\hline \multicolumn{1}{c}{ Variables } & Findings \\
\hline cblC defect & \\
$\quad$ Biochemical & $94 \%(n=34 / 36)$ \\
$\quad$ Genetic & $50 \%(n=18 / 36)$ \\
Mutations (allelic frequency) & \\
c.271dupA & $36 \%(n=13 / 36)$ \\
c.276G $>\mathrm{T}$ & $17 \%(n=6 / 36)$ \\
c.565C $>\mathrm{A}$ & $11 \%(n=4 / 36)$ \\
Complement system & \\
Normal & $87 \%(n=13 / 15)$ \\
CFH-autoantibodies & $6.6 \%(n=1 / 15)$ \\
CFH mutation & $6.6 \%(n=1 / 15)$ \\
\hline
\end{tabular}

classic triad of hemolytic anemia, uremia, and thrombopenia [40]. Renal biopsies or autopsies were performed in 16 patients and revealed TMA in all of them (in two patients who were initially classified as membranoproliferative glomerulonephritis, biopsy reanalysis was consistent with TMA [31]). In general, a uniform histomorphological pattern was noted (Fig. 3, Table 5): glomerular thrombi and swelling were described in 13 cases. Duplication of the glomerular basement membrane was noted in all but one patient and intra-arterial thrombi was seen in nine.

Complement defects were detected in two of 15 patients screened for potential atypical HUS (aHUS): patient $20 \mathrm{had}$ antifactor $\mathrm{H}$ autoantibodies and died from pulmonary hypertension despite treatment with hydroxycobalamin. Patient 27 had a mutation in $C F H$, underwent plasmapheresis and renal replacement therapy (RRT), and responded well to treatment with hydroxycobalamin (see Tables 6 and S1). Of the 32 patients with reduced renal function, eight required dialysis and two received a kidney graft. In four patients, glomerular filtration rate was within normal limits. Hematuria and proteinuria were present in all tested patients $(n=27$, Table 4); three of them presented with frank nephrotic syndrome [22, 30]. Arterial hypertension was reported in 18 patients. Thirty-one patients were treated with hydroxycobalamin; 17 of them improved clinically, two stabilized, and 12 died (Table 6). In $81 \%$ of the survivors, renal function improved. In children and adolescents, glomerular filtration rate (GFR) increased from 49.5 to $89 \mathrm{ml} / \mathrm{min} / 1.73 \mathrm{~m}^{2}$. Two patients were treated with cyanocobalamin (which is ineffective to overcome the metabolic block in MMACHC patients): one of them died, and no improvement of renal function was observed in the other. Three patients did not receive metabolic treatment and died.

Five patients were treated with complement-targeted therapy (Table 6), of whom, one (patient 27 with a 3254T3 C 


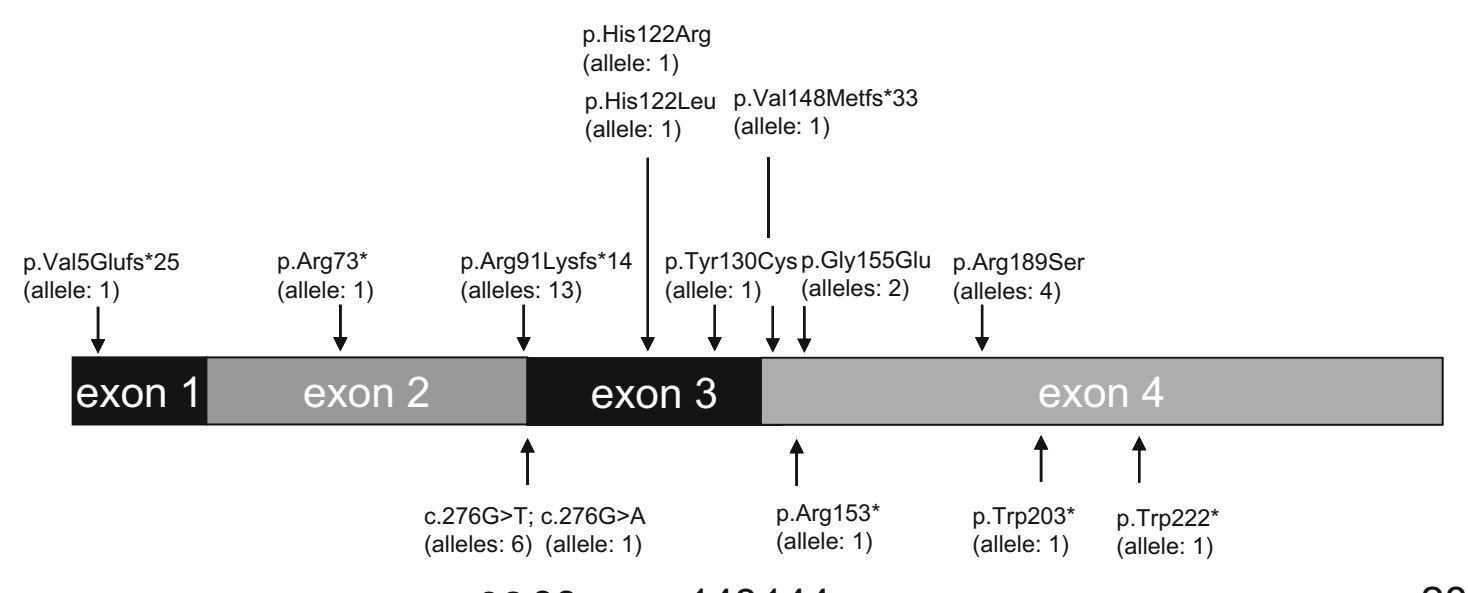

$\begin{array}{lllll}\text { AA1 } & 2728 & 9293 & 143144 & 282\end{array}$

Fig. 2 Methylmalonic aciduria and homocystinuria, cobalamine $\mathrm{C}$ (cblC) complementation type (MMACHC) mutations in patients with renal thrombotic microangiopathy (TMA). Protein prediction is

mutation in factor $\mathrm{H}$ ) responded. In the four nonresponders, no complement defect was detected. Mortality was higher in infants $(57 \%)$ compared with later-onset disease $(35 \%)$, resulting in an overall mortality rate of $44 \%$. Extrarenal involvement included neurological and cardiopulmonary disease in 44 and $39 \%$ of patients, respectively (Table 4). It is noteworthy that among the 16 nonsurvivors, 11 patients had cardiopulmonary involvement. In seven patients, pulmonary arterial hypertension was diagnosed by right ventricle catheterization and/or cardiac ultrasound; it was fatal in four.

Table 4 Methylmalonic aciduria and homocystinuria, cobalamin C (cblC) complementation type (MMACHC): general, renal, and extrarenal characteristics

\begin{tabular}{ll}
\hline Manifestation data & \\
\hline Onset of disease & \\
$\quad$ Infantile onset & $44 \%,(n=16 / 36)$ \\
$\quad$ Noninfantile onset & $56 \%,(n=20 / 36)$ \\
Characteristics of renal disease & \\
$\quad$ Proteinuria and hematuria & $100 \%,(n=27 / 27)$ \\
$\quad$ Hemolytic uremic syndrome & $66 \%,(n=24 / 36)$ \\
Normotensive & $10 \%,(n=2 / 20)$ \\
Hypertensive & $90 \%,(n=18 / 20)$ \\
Nephrotic syndrome & $11 \%,(n=3 / 27)$ \\
Chronic kidney disease (CKD) 1 & $11 \%,(n=4)$ \\
CKD 2-5 & $89 \%,(n=32)$ \\
Dialysis & $22 \%,(n=8)$ \\
Kidney transplant & $6 \%,(n=2)$ \\
Extrarenal manifestations & \\
Neurological impairment & $44 \%,(n=16 / 36)$ \\
Cardiopulmonary involvement & $39 \%,(n=14 / 36)$ \\
Pulmonary hypertension & $17 \%,(n=6 / 36)$ \\
\hline
\end{tabular}

depicted for all identified MMACHC mutations, except for the splice changes, which are indicated at the complementary DNA (cDNA) level

\section{Discussion}

\section{Clinical, histopathological, and genetic characteristics} of renal disease in cblC defect

The key findings in the 36 patients with MMACHC and renal disease are as follows:

(1) In general, the first manifestation of renal disease occurs early in infancy, although onset can vary widely among
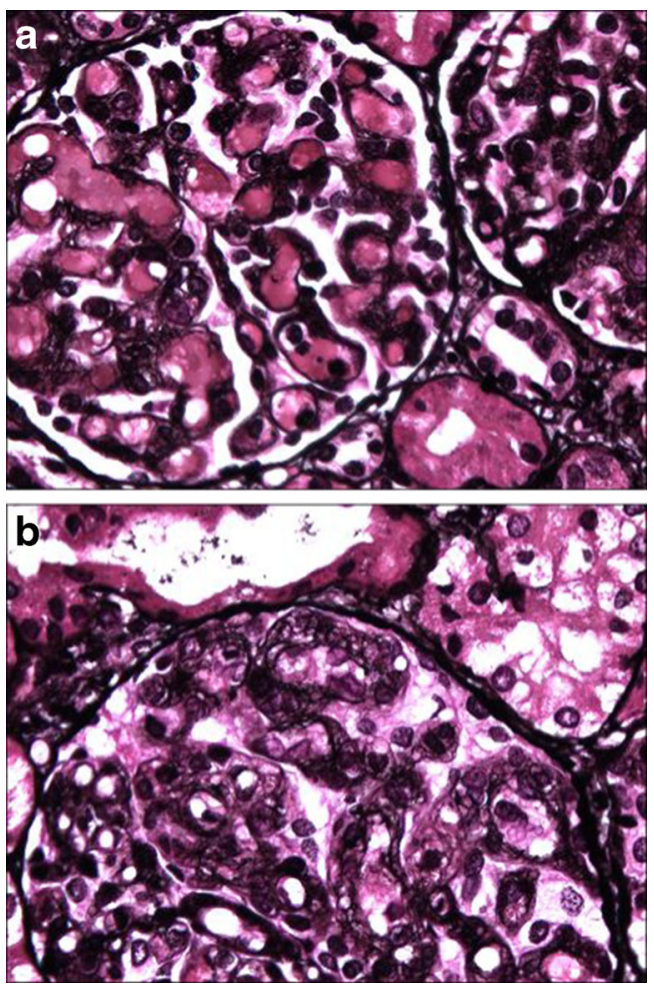

Fig. 3 Representative renal histology in cobalamin $\mathrm{C}$ (clbC) defect. a Fibrin thrombi in the majority of glomerular capillaries (patient 18). b Thickening and splitting of the glomerular basement membrane (patient 18) 
Table 5 Renal histology

\begin{tabular}{|c|c|c|c|c|c|c|c|c|c|c|c|c|c|c|c|c|}
\hline Patient no. & 1 & 2 & 9 & 10 & 16 & 18 & 20 & 22 & 24 & 26 & 27 & 28 & 25 & 30 & 31 & 34 \\
\hline Ischemia & & & & & & & & & & & $\mathrm{y}$ & & & & & \\
\hline Intra-arterial thrombi & $\mathrm{y}$ & $\mathrm{n}$ & $\mathrm{n}$ & $\mathrm{y}$ & $\mathrm{n}$ & $\mathrm{y}$ & $\mathrm{y}$ & $\mathrm{y}$ & $\mathrm{y}$ & & $\mathrm{y}$ & $\mathrm{y}$ & & & & $\mathrm{y}$ \\
\hline Glomerular thrombi & $\mathrm{y}$ & & & $\mathrm{y}$ & $\mathrm{y}$ & $\mathrm{y}$ & $\mathrm{y}$ & $\mathrm{y}$ & & $\mathrm{y}$ & $\mathrm{y}$ & $\mathrm{y}$ & $\mathrm{y}$ & $\mathrm{y}$ & $\mathrm{y}$ & $\mathrm{y}$ \\
\hline \multicolumn{17}{|l|}{ Endothelial } \\
\hline Swelling & & $\mathrm{y}$ & $\mathrm{n}$ & & $\mathrm{y}$ & & & $\mathrm{y}$ & $\mathrm{y}$ & $\mathrm{y}$ & $\mathrm{y}$ & $\mathrm{y}$ & $\mathrm{y}$ & $\mathrm{y}$ & $\mathrm{y}$ & $\mathrm{y}$ \\
\hline Detachment & & $\mathrm{y}$ & $\mathrm{n}$ & & $\mathrm{y}$ & & & & & & & & & & & \\
\hline Duplication of GBM & & $\mathrm{y}$ & $\mathrm{n}$ & & $\mathrm{y}$ & $\mathrm{y}$ & $\mathrm{y}$ & $\mathrm{y}$ & $\mathrm{y}$ & $\mathrm{y}$ & $\mathrm{y}$ & $\mathrm{y}$ & $\mathrm{y}$ & $\mathrm{y}$ & $\mathrm{y}$ & $\mathrm{y}$ \\
\hline Glomerular sclerosis & & $\mathrm{n}$ & $\mathrm{n}$ & & $\mathrm{n}$ & $\mathrm{n}$ & $\mathrm{n}$ & $\mathrm{n}$ & $\mathrm{n}$ & $\mathrm{n}$ & $\mathrm{n}$ & $\mathrm{n}$ & $\mathrm{y}$ & $\mathrm{n}$ & $\mathrm{n}$ & $\mathrm{n}$ \\
\hline
\end{tabular}

$y$ yes, $n$ no, GBM glomerular basement membrane

affected individuals (median onset is 1.5 months, range 12 days to 40 years).

(2) Overall mortality is high (44\%).

(3) Mortality is primarily the result of cardiopulmonary problems (68\%), with pulmonary hypertension identified as a specific cause in seven patients (44\%).

(4) Renal impairment (as defined by reduced glomerular filtration) is variable and ranges from insignificant to initiation of RRT, which is necessary in $22 \%$ of patients.

(5) Consistent features of renal disease in all patients are intravascular hemolysis, hematuria, and proteinuria.

(6) Consistently, pathological changes predominantly show glomerular thrombotic microangiopathies [41], including glomerular fibrin thrombi, endothelial swelling, and duplication of the glomerular basement membrane.

(7) The majority of patients respond to therapy with hydxroycobalamin.

Table 6 Response to metabolic and complement-targeted therapy

\begin{tabular}{ll} 
Response to metabolic therapy & \\
\hline Clinical recovery & $54 \%, n=17$ \\
Improvement of GFR & $81 \%, n=13$ \\
Stable GFR & $19 \%, n=3$ \\
Pretreatment GFR $\left(\mathrm{ml} / \mathrm{min} / 1.73 \mathrm{~m}^{2}\right)$ & $49.5 n=10$ \\
Posttreatment GFR $\left(\mathrm{ml} / \mathrm{min} / 1.73 \mathrm{~m}^{2}\right)$ & $89, n=10$ \\
Mortality & \\
Overall mortality & $44 \%(n=16 / 36)$ \\
Infantile onset & $56 \%,(n=9 / 16)$ \\
Noninfantile onset & $35 \%,(n=7 / 20)$ \\
With neurological disease & $50 \%,(n=8 / 16)$ \\
With cardiopulmonary disease & $79 \%,(n=11 / 14)$ \\
Untreated & $100 \%,(n=4 / 4)$ \\
Complement-targeted therapy (response) & \\
Plasma exchange (patients $22,24,27,33)$ & $1 *$ out of 4 \\
Eculizumab (patients 33, 34) & No response \\
\hline
\end{tabular}

GFR glomerular filtration rate
(8) As could be expected from its high allelic frequency, the frameshift mutation c.271dupA represented the most frequent allele in our cohort, followed by the splice-site mutation c. $276 \mathrm{G}>\mathrm{T}$ and the missense mutation c.565C $>\mathrm{A}$. As all patients with a c. $276 \mathrm{G}>\mathrm{T}$ allele originated from the Dutch "Bible belt" or adjacent regions in Germany, a founder effect is highly likely here.

\section{Pathophysiologic considerations}

Given the fact that all patients demonstrated microangiopathic hemolytic anemia [elevated lactose dehydrogenase (LDH), reduced haptoglobin levels, and/or fragmentocytes), the concept of endothelial cell damage appears to be a central pathogenic factor. This notion is clearly supported by the histological evidence of endothelial damage, i.e., endothelial swelling, detachment, and duplication of the glomerular basement membrane. The fact that the latter was observed in all but one case probably reflects the chronicity of the lesions.

The etiology of endothelial damage remains largely unknown. Homocysteine, unlike methylmalonic acid, is known to damage endothelial cells [42]. Half of the patients in this review had intermediate levels of homocysteinemia (30$100 \mu \mathrm{mol} / \mathrm{l})$ at presentation; the others showed severe hyperhomocysteinemia (homocysteine levels $>100 \mu \mathrm{mol} / \mathrm{l}$ ). Interestingly, isolated (i.e. without methylmalonic acidemia) intermediate or even severe hyperhomocysteinemia-as observed in methylenetetrahydrofolate reductase (MTHFR) deficiency (OMIM 607093) or in homocystinuria due to cystathionine beta-synthase (CBS) deficiency (OMIM 236200) - have not been reported to cause any specific renal (e.g., HUS) or cardiopulmonary (e.g., pulmonary hypertension) disease apart from thromboembolism. Possibly, additional biochemical abnormalities such as methylmalonic acidemia and/or methionine deficiency — as in cblC defect (this study) or in methylenetetrahydrofolate dehydrogenase 1 (MTHFD1) deficiency (OMIM 172460, [43, 44]) - are required to develop TMA. The notion that it takes two or more toxic metabolites to trouble endothelial cells is supported by 
the occasional occurrence of pseudo-TMA in nutritional $\mathrm{B}_{12}$ deficiency [45], which-like MMACHC and MTHFD1 deficiency - is characterized by combined hyperhomocysteinemia and methylmalonic acidemia and low methionine levels. This would also hold true for such findings in some other $\mathrm{Cbl}$ defects, such as cblD, cblF, cblJ, and cblX variants, which are much more rare [3].

The fact that only a subgroup (minimum 36 of $>500$ reported patients) of patients with MMACHC are affected by TMA requires further investigation. Apart from the reduced penetrance seen in many mendelian disorders, other factors in addition to homocysteine levels could contribute to the manifestation of TMA. This fits with the observation of discordant families in a recent study reporting asymptomatic MMACHC cases (prior to treatment with hydroxylcobalamin) [46] and one from our hospital [clinically unaffected sister of patient 29 (homozygous for c.276G $>$ T)] with comparable homocysteine levels (Kömhoff, and Berger, unpublished data). That TMA may be underreported because its features are too subtle in the presence of a predominant neurocognitive or cardiopulmonary disease or because the patient dies before renal disease develops cannot be excluded.

Comparison of the the study reported here with cohorts of children with suspected or proven aHUS/complement defects $[47,48]$ allows a number of interesting considerations: median age of presentation in MMACHC with renal disease (1.5 months) was much earlier than in the French ( 1.5 years, [47]) or Dutch (80\% older than 1 year of age at presentation, [48]) aHUS cohorts. Renal impairment, however, was much more pronounced in both the Dutch and French aHUS cohorts, with $44 \%$ [48] and $59 \%$ [47], respectively, of patients requiring RRT at presentation, compared with $22 \%$ in MMACHC. Early presentation with relatively mild renal impairment probably reflects that MMACHC is a severe systemic disease resulting in early referral for multiple reasons when renal disease has not yet advanced. In contrast to the comparatively low mortality of $2 \%$ [48] and $8 \%$ [47] in the Dutch and French aHUS cohorts, respectively, overall mortality with cblC defect is high (44\%). In 11 of the 16 nonsurvivors, a cardiopulmonary problem was noted, with pulmonary arterial hypertension diagnosed in seven. The concept of cardiorenal syndrome with pulmonary hypertension and TMA in MMACHC deficiency is supported by hemolytic anemia in an infant with cblC defect who died from cor pulmonale [49] and by increased creatinine and LDH levels in another infant who died from pulmonary hypertension and MMACHC [50]. The increased risk for pulmonary hypertension should thus prompt a thorough evaluation of MMACHC patients by a pediatric cardiologist with expertise in pulmonary hypertension.

\section{Diagnosis}

MMACHC should be considered in all children, adolescents, and young adults with unclear intravascular hemolysis, hematuria, and proteinuria, irrespective of renal and neurological impairment. Homocysteine blood concentrations $>20 \mu \mathrm{mol} / 1$ with normal renal function and $>30$ with renal failure require further biochemical and genetic workup [4]. It is important to realize that total $\mathrm{Cbl}$ levels are unrealiable indicators of a functional $\mathrm{Cbl}$ deficiency [51].

\section{Therapy}

The general principles of metabolic therapy have recently been described in detail [4]. Whenever MMACHC is suspected, we consider it mandatory to promptly initiate treatment with parenteral administration of hydroxycobalamin without waiting for confirmation by genetic testing. A practical guideline is given in Table 3. It should be kept in mind, however, that some patients are difficult to treat, even with intense therapy [52]. In the event of a patient with TMA and pulmonary hypertension in whom MMACHC and a complement defect coincide (Table S1, patient 20), we strongly advocate the use of a C5 inhibitor [53] instead of plasma exchange to inhibit complement activation, as the latter carries an extremely high risk for transfusion-related acute lung injury (TRALI) [54]. When general anesthesia is required, it should be taken into account that nitrous oxide is potentially toxic to patients with MMACHC disease and needs to be avoided, because it depletes the body stores of $\mathrm{B}_{12}$ and inhibits methionine synthase activity $[55,56]$ Table 7.

Table 7 Metabolic therapy in patients with cobalamin C (cblC) defect (modified from [4], used with permission)

\begin{tabular}{|c|c|c|c|c|}
\hline Medication & Recommended dose & Frequency & Efficacy & Target biochemical parameter \\
\hline $\begin{array}{l}\text { Hydroxycobalamin: i.m., } \\
\text { i.v. or intranasally [20] }\end{array}$ & $0.3 \mathrm{mg} / \mathrm{kg} /$ day & Start once daily & Established & $\begin{array}{l}\text { Reducing serum MMA and tHCY levels } \\
\text { Normalizing plasma MET and } \\
\text { hematological parameters }\end{array}$ \\
\hline Betaine oral & $250 \mathrm{mg} / \mathrm{kg} /$ day & tid & Established & Reducing HCY, increasing MET \\
\hline Folinic acid oral & $5-15 \mathrm{mg} /$ day & tid & Theoretical & Reducing HCY, increasing MET \\
\hline Levocarnitine oral & $50-100 \mathrm{mg} / \mathrm{kg} /$ day & tid & Theoretical & Unnecessary in case of normal MET \\
\hline
\end{tabular}

$H C Y$ homocysteine, MET methionine, MMA methylmalonic acid, tid three times a day 
This retrospective analysis has significant limitations mainly resulting from (a) the long period ( $>35$ years) over which patients were reported and during which significant advances have been made in the field of diagnostics and therapeutics; and (b) the heterogeneity of centers using different diagnostic and therapeutic approaches. We think, however, that the consistent features of MMACHC compensate for the heterogeneity and thereby allow us to draw the following valid conclusions:

Renal TMA due to CblC defect is a devastating disease with high mortality in which mild renal impairment may distract the nephrologist from detecting severe cardiopulmonary involvement. However, when recognized and treated at an early stage, complete clinical recovery is possible. Diagnosis is simple, and therapy is cheap and successful in the majority of patients. We therefore strongly recommend [57] sceening for MMACHC in all patients with intravascular hemolysis in combination with hematuria and proteinuria.

\section{Compliance with ethical standards}

Conflict of interest The authors declare no conflict interest.

Open Access This article is distributed under the terms of the Creative Commons Attribution 4.0 International License (http:// creativecommons.org/licenses/by/4.0/), which permits unrestricted use, distribution, and reproduction in any medium, provided you give appropriate credit to the original author(s) and the source, provide a link to the Creative Commons license, and indicate if changes were made.

\section{References}

1. Eschenmoser A (2011) Etiology of potentially primordial biomolecular structures: from vitamin B12 to the nucleic acids and an inquiry into the chemistry of life's origin: a retrospective. Angew Chem Int Ed Engl 50:12412-12472

2. Roth JR, Lawrence JG, Bobik TA (1996) Cobalamin (coenzyme B12): synthesis and biological significance. Annu Rev Microbiol 50:137-181

3. Froese DS, Gravel RA (2010) Genetic disorders of vitamin B(1)(2) metabolism: eight complementation groups - eight genes. Expert Rev Mol Med 12:e37

4. Carrillo-Carrasco N, Chandler RJ, Venditti CP (2012) Combined methylmalonic acidemia and homocystinuria, cblC type I. Clinical presentations, diagnosis and management. J Inherit Metab Dis 35: 91-102

5. Mudd SH, Levy HL, Abeles RH, Jennedy JP Jr (1969) A derangement in B 12 metabolism leading to homocystinemia, cystathioninemia and methylmalonic aciduria. Biochem Biophys Res Commun 35:121-126

6. Gravel RA, Mahoney MJ, Ruddle FH, Rosenberg LE (1975) Genetic complementation in heterokaryons of human fibroblasts defective in cobalamin metabolism. Proc Natl Acad Sci U S A 72:3181-3185

7. Harding CO, Pillers DA, Steiner RD, Bottiglieri T, Rosenblatt DS, Debley J, Michael Gibson K (2003) Potential for misdiagnosis due to lack of metabolic derangement in combined methylmalonic aciduria/hyperhomocysteinemia (cblC) in the neonate. J Perinatol 23:384-386
8. Carrillo-Carrasco N, Venditti CP (2012) Combined methylmalonic acidemia and homocystinuria, cblC type. II. Complications, pathophysiology, and outcomes. J Inherit Metab Dis 35:103-114

9. Lerner-Ellis JP, Tirone JC, Pawelek PD, Doré C, Atkinson JL, Watkins D, Morel CF, Fujiwara TM, Moras E, Hosack AR, Dunbar GV, Antonicka H, Forgetta V, Dobson CM, Leclerc D, Gravel RA, Shoubridge EA, Coulton JW, Lepage P, Rommens JM, Morgan K, Rosenblatt DS (2006) Identification of the gene responsible for methylmalonic aciduria and homocystinuria, cblC type. Nat Genet 38:93-100

10. Banerjee R (2006) B12 trafficking in mammals: a for coenzyme escort service. ACS Chem Biol 1:149-159

11. Kim J, Gherasim C, Banerjee R (2008) Decyanation of vitamin B12 by a trafficking chaperone. Proc Natl Acad Sci U S A 105:14551-14554

12. Moreno-Garcia MA, Pupavac M, Rosenblatt DS, Tremblay ML, Jerome-Majewska LA (2014) The Mmachc gene is required for pre-implantation embryogenesis in the mouse. Mol Genet Metab 112:198-204

13. Weisfeld-Adams JD, Morrissey MA, Kirmse BM, Salveson BR, Wasserstein MP, McGuire PJ, Sunny S, Cohen-Pfeffer JL, Yu C, Caggana M, Diaz GA (2010) Newborn screening and early biochemical follow-up in combined methylmalonic aciduria and homocystinuria, cblC type, and utility of methionine as a secondary screening analyte. Mol Genet Metab 99:116-123

14. Sonsino E, Ogier H, Mercier JC, Devictor D, Ferkdadji L, Bocquet L (1985) Congenital anomaly of the metabolism of vitamin B 12. Histopathological study. Arch Anat Cytol Pathol 33:98-99

15. Lerner-Ellis JP, Anastasio N, Liu J, Coelho D, Suormala T, Stucki M, Loewy AD, Gurd S, Grundberg E, Morel CF, Watkins D, Baumgartner MR, Pastinen T, Rosenblatt DS, Fowler B (2009) Spectrum of mutations in MMACHC, allelic expression, and evidence for genotype-phenotype correlations. Hum Mutat 30:1072-1081

16. Liu MY, Yang YL, Chang YC, Chiang SH, Lin SP, Han LS, Qi Y, Hsiao KJ, Liu TT (2010) Mutation spectrum of MMACHC in Chinese patients with combined methylmalonic aciduria and homocystinuria. J Hum Genet 55:621-626

17. Watkins D, Rosenblatt DS (2011) Inborn errors of cobalamin absorption and metabolism. Am J Med Genet C: Semin Med Genet 157C:33-44

18. Fischer S, Huemer M, Baumgartner M, Deodato F, Ballhausen D, Boneh A, Burlina AB, Cerone R, Garcia P, Gökçay G, Grünewald S, Häberle J, Jaeken J, Ketteridge D, Lindner M, Mandel H, Martinelli D, Martins EG, Schwab KO, Gruenert SC, Schwahn BC, Sztriha L, Tomaske M, Trefz F, Vilarinho L, Rosenblatt DS, Fowler B, DionisiVici C (2014) Clinical presentation and outcome in a series of 88 patients with the cblC defect. J Inherit Metab Dis 37:831-840

19. Baumgartner ER, Wick H, Maurer R, Egli N, Steinmann B (1979) Congenital defect in intracellular cobalamin metabolism resulting in homocysteinuria and methylmalonic aciduria. I. Case report and histopathology. Helv Paediatr Acta 34:465-482

20. Slot WB, Merkus FW, Van Deventer SJ, Tytgat GN (1997) Normalization of plasma vitamin B12 concentration by intranasal hydroxocobalamin in vitamin B12-deficient patients. Gastroenterology 113:430-433

21. Li QL, Song WQ, Peng XX, Liu XR, He LJ, Fu LB (2015) Clinical characteristics of hemolytic uremic syndrome secondary to cobalamin C disorder in Chinese children. World J Pediatr 11:276-280

22. Koenig JC, Rutsch F, Bockmeyer C, Baumgartner M, Beck BB, Kranz B, Konrad M (2015) Nephrotic syndrome and thrombotic microangiopathy caused by cobalamin $\mathrm{C}$ deficiency. Pediatr Nephrol 30:1203-1206

23. Carmel R, Bedros AA, Mace JW, Goodman SI (1980) Congenital methylmalonic aciduria-homocystinuria with megaloblastic anemia: observations on response to hydroxocobalamin and on the effect of homocysteine and methionine on the deoxyuridine suppression test. Blood 55:570-579 
24. Jiménez Varo I, Bueno Delgado M, Dios Fuentes E, Delgado Pecellin C, González Meneses A, Soto Moreno A, Venegas Moreno E (2015) Combined methylmalonic acidemia and homocystinuria; a case report. Nutr Hosp 31:1885-1888

25. Cornec-Le Gall E, Delmas Y, De Parscau L, Doucet L, Ogier H, Benoist JF, Fremeaux-Bacchi V, Le Meur Y (2014) Adult-onset eculizumab-resistant hemolytic uremic syndrome associated with cobalamin C deficiency. Am J Kidney Dis 63:119-123

26. Kömhoff M, Roofthooft MT, Westra D, Teertstra TK, Losito A, van de Kar NC, Berger RM (2013) Combined pulmonary hypertension and renal thrombotic microangiopathy in cobalamin $\mathrm{C}$ deficiency. Pediatrics 132:e540-e544

27. Menni F, Testa S, Guez S, Chiarelli G, Alberti L, Esposito S (2012) Neonatal atypical hemolytic uremic syndrome due to methylmalonic aciduria and homocystinuria. Pediatr Nephrol 27:1401-1405

28. Bouts AH, Roofthooft MT, Salomons GS, Davin JC (2010) CD46associated atypical hemolytic uremic syndrome with uncommon course caused by cblC deficiency. Pediatr Nephrol 25:2547-2548

29. Sharma AP, Greenberg CR, Prasad AN, Prasad C (2007) Hemolytic uremic syndrome (HUS) secondary to cobalamin $\mathrm{C}$ (cblC) disorder. Pediatr Nephrol 22:2097-2103

30. Guigonis V, Frémeaux-Bacchi V, Giraudier S, Favier R, Borderie D, Massy Z, Mougenot B, Rosenblatt DS, Deschênes G (2005) Late-onset thrombocytic microangiopathy caused by cblC disease: association with a factor $\mathrm{H}$ mutation. Am J Kidney Dis 45:588-595

31. Van Hove JL, Van Damme-Lombaerts R, Grünewald S, Peters H, Van Damme B, Fryns JP, Arnout J, Wevers R, Baumgartner ER, Fowler B (2002) Cobalamin disorder Cbl-C presenting with lateonset thrombotic microangiopathy. Am J Med Genet 111:195-201

32. Kind T, Levy J, Lee M, Kaicker S, Nicholson JF, Kane SA (2002) Cobalamin $\mathrm{C}$ disease presenting as hemolytic-uremic syndrome in the neonatal period. J Pediatr Hematol Oncol 24:327-329

33. Chenel C, Wood C, Gourrier E, Zittoun J, Casadevall I, Ogier H (1993) Neonatal hemolytic-uremic syndrome, methylmalonic aciduria and homocystinuria caused by intracellular vitamin B 12 deficiency. Value of etiological diagnosis. Arch Fr Pediatr 50:749-754

34. Geraghty MT, Perlman EJ, Martin LS, Hayflick SJ, Casella JF, Rosenblatt DS, Valle D (1992) Cobalamin C defect associated with hemolytic-uremic syndrome. J Pediatr 120:934-937

35. Huemer M, Scholl-Bürgi S, Hadaya K, Kern I, Beer R, Seppi K, Fowler B, Baumgartner MR, Karall D (2014) Three new cases of late-onset cblC defect and review of the literature illustrating when to consider inborn errors of metabolism beyond infancy. Orphanet $\mathbf{J}$ Rare Dis 9:161

36. Richard E, Jorge-Finnigan A, Garcia-Villoria J, Merinero B, Desviat LR, Gort L, Briones P, Leal F, Pérez-Cerdá C, Ribes A, Ugarte M, Pérez B, MMACHC Working Group (2009) Genetic and cellular studies of oxidative stress in methylmalonic aciduria (MMA) cobalamin deficiency type $\mathrm{C}$ (cblC) with homocystinuria (MMACHC). Hum Mutat 30:1558-1566

37. Thauvin-Robinet C, Roze E, Couvreur G, Horellou MH, Sedel F, Grabli D, Bruneteau G, Tonneti C, Masurel-Paulet A, Perennou D, Moreau T, Giroud M, de Baulny HO, Giraudier S, Faivre L (2008) The adolescent and adult form of cobalamin $\mathrm{C}$ disease: clinical and molecular spectrum. J Neurol Neurosurg Psychiatry 79:725-728

38. Brunelli SM, Meyers KE, Guttenberg M, Kaplan P, Kaplan BS (2002) Cobalamin C deficiency complicated by an atypical glomerulopathy. Pediatr Nephrol 17:800-803

39. Benz K, Amann K (2010) Thrombotic microangiopathy: new insights. Curr Opin Nephrol Hypertens 19:242-247

40. Gasser C, Gautier E, Steck A, Siebenmann RE, Oechslin R (1955) Hemolytic-uremic syndrome: bilateral necrosis of the renal cortex in acute acquired hemolytic anemia. Schweiz Med Wochenschr 85: 905-909
41. Renaud C, Niaudet P, Gagnadoux MF, Broyer M, Habib R (1995) Haemolytic uraemic syndrome: prognostic factors in children over 3 years of age. Pediatr Nephrol 9:24-29

42. Mangge H, Becker K, Fuchs D, Gostner JM (2014) Antioxidants, inflammation and cardiovascular disease. World J Cardiol 6:462-477

43. Keller MD, Ganesh J, Heltzer M, Paessler M, Bergqvist AG, Baluarte HJ, Watkins D, Rosenblatt DS, Orange JS (2013) Severe combined immunodeficiency resulting from mutations in MTHFD1. Pediatrics 131:e629-e634

44. Watkins D, Schwartzentruber JA, Ganesh J, Orange JS, Kaplan BS, Nunez LD, Majewski J, Rosenblatt DS (2011) Novel inborn error of folate metabolism: identification by exome capture and sequencing of mutations in the MTHFD1 gene in a single proband. J Med Genet 48:590-592

45. Andrès E, Affenberger S, Zimmer J, Vinzio S, Grosu D, Pistol G, Maloisel F, Weitten T, Kaltenbach G, Blicklé JF (2006) Current hematological findings in cobalamin deficiency. A study of 201 consecutive patients with documented cobalamin deficiency. Clin Lab Haematol 28:50-56

46. Han L, Wu S, Ye J, Qiu W, Zhang H, Gao X, Wang Y, Gong Z, Jin J, $\mathrm{Gu} X$ (2015) Biochemical, molecular and outcome analysis of eight chinese asymptomatic individuals with methyl malonic acidemia detected through newborn screening. Am J Med Genet A 167A: 2300-2305

47. Fremeaux-Bacchi V, Fakhouri F, Garnier A, Bienaimé F, DragonDurey MA, Ngo S, Moulin B, Servais A, Provot F, Rostaing L, Burtey S, Niaudet P, Deschênes G, Lebranchu Y, Zuber J, Loirat C (2013) Genetics and outcome of atypical hemolytic uremic syndrome: a nationwide French series comparing children and adults. Clin J Am Soc Nephrol 8:554-562

48. Geerdink LM, Westra D, van Wijk JA, Dorresteijn EM, Lilien MR, Davin JC, Kömhoff M, Van Hoeck K, van der Vlugt A, van den Heuvel LP, van de Kar NC (2012) Atypical hemolytic uremic syndrome in children: complement mutations and clinical characteristics. Pediatr Nephrol 27:1283-1291

49. Brandstetter Y, Weinhouse E, Splaingard ML, Tang TT (1990) Cor pulmonale as a complication of methylmalonic acidemia and homocystinuria (Cbl-C type). Am J Med Genet 36:167-171

50. Iodice FG, Di Chiara L, Boenzi S, Aiello C, Monti L, Cogo P, Dionisi-Vici C (2013) Cobalamin C defect presenting with isolated pulmonary hypertension. Pediatrics 132:e248-e251

51. Solomon LR (2007) Disorders of cobalamin (vitamin B12) metabolism: emerging concepts in pathophysiology, diagnosis and treatment. Blood Rev 21:113-130

52. Carrillo-Carrasco N, Sloan J, Valle D, Hamosh A, Venditti CP (2009) Hydroxocobalamin dose escalation improves metabolic control in cblC. J Inherit Metab Dis 32:728-731

53. Zuber J, Fakhouri F, Roumenina LT, Loirat C, Frémeaux-Bacchi V, French Study Group for aHUS/C3G (2012) Use of eculizumab for atypical haemolytic uraemic syndrome and $\mathrm{C} 3$ glomerulopathies. Nat Rev Nephrol 8:643-657

54. MacLennan S, Barbara JA (2006) Risks and side effects of therapy with plasma and plasma fractions. Best Pract Res Clin Haematol 19: 169-189

55. Abels J, Kroes AC, Ermens AA, van Kapel J, Schoester M, Spijkers LJ, Lindemans J (1990) Anti-leukemic potential of methylcobalamin inactivation by nitrous oxide. Am J Hematol 34:128-131

56. Drummond JT, Matthews RG (1994) Nitrous oxide degradation by cobalamin-dependent methionine synthase: characterization of the reactants and products in the inactivation reaction. Biochemistry 33 : 3732-3741

57. Komhoff M, Roofthooft MT, Spronsen F (2014) Syndromes of thrombotic microangiopathy. N Engl J Med 371:1846-1847 